zem żywej sympatii i niesłabnącego szacunku środowiska naukowego wobec Jubilata, ale - co też jest niezwykle istotne - także L. Mokrzeckiego obrazem życzliwego stosunku wobec życia, nauki, sztuki i ludzi.

Dlatego praca $W$ slużbie nauki, kultury $i$ edukacji... jest jedynie dopełnieniem, cennym, co należy podkreślić, ładnie i starannie edytorsko przygotowanym, tego pomnika, który Profesor wystawił sam sobie w ludzkich sercach.

Edyta Glowacka-Sobiech

\begin{abstract}
Agnieszka Wałęga, Poczqtki akademickiej historii wychowania w Polsce. Antoni Karbowiak (1856-1919), Wydawnictwo Uniwersytetu Mikołaja Kopernika, Toruń 2007, ss. 193
\end{abstract}

Już blisko dziewięćdziesiąt lat minęło od czasu, gdy historia wychowania stała się samodzielną dyscypliną akademicką. Stało się to możliwe dzięki zorganizowaniu na początku lat dwudziestych ubiegłego stulecia, na Uniwersytetach w Krakowie i we Lwowie, katedr prowadzących badania dziejów oświaty i edukacji. Przez dziesięciolecia prowadzona tam, oraz w kolejno powoływanych ośrodkach, działalność naukowa wiązała się z aktywnością wielu wybitnych profesorów, wśród których szczególne zasługi położył urodzony w Wielkopolsce Antoni Karbowiak - uczony, który pierwszy w Polsce habilitował się z zakresu historii wychowania. Stąd też wydaje się być niezwykle cennym ukazanie się monografii autorstwa Agnieszki Wałęgi, poświęconej analizie jego dorobku naukowego.

Książka jest publikacją rozprawy doktorskiej, obronionej w 2005 r. na Wydziale Humanistycznym Uniwersytetu Mikołaja Kopernika w Toruniu. Jest biografią Antoniego Karbowiaka jako historyka wychowania, ujętą z perspektywy historycznej, pedagogicznej i oświatowej, w której zastosowano układ chronologiczno-problemowy.

Praca składa się z trzech części, poprzedzonych wstępem, a zakończonych bibliografią oraz indeksem osób. Ponadto została zaopatrzona w aneksy, zawierające zdjęcie Antoniego Karbowiaka oraz fotokopie najważniejszych dokumentów źródłowych, pochodzących ze zbiorów Archiwum Uniwersytetu Jagiellońskiego, obrazujących jego karierę naukową.

Pierwsza część pracy zarysowuje sytuację polskiej historii oświaty i wychowania przełomu XIX i XX w. Autorka zrekonstruowała narodziny i dynamiczny rozwój historii wychowania, prowadzący do uznania jej w pierwszej połowie XX w. za samodzielną dyscyplinę uniwersytecką. Proces ten był możliwy dzięki powstaniu zajmujących się tą tematyką instytucji naukowych, rozpoczęciu profesjonalnych badań historyczno-oświatowych, włączeniu historii wychowania do obowiązkowych przedmiotów wykładowych dla przyszłych nauczycieli, zredagowaniu podręczników i skryptów oraz powołaniu pierwszych katedr zajmujących się badaniem dziejów oświaty i wychowania w Krakowie (1920) i we Lwowie (1924). Mimo swej niewielkiej objętości, omawiana część pracy w sposób syntetyczny ujmuje główne problemy historii wychowania czasów działalności 
Antoniego Karbowiaka i pozwala na lepsze zrozumienie problemów poruszanych w kolejnych rozdziałach.

Życie oraz aktywność pedagogiczna i naukowa Karbowiaka do czasu jego nominacji na profesora nadzwyczajnego Uniwersytetu Jagiellońskiego w 1919 r. stanowi przedmiot drugiej części pracy. W kolejnych podrozdziałach interesujące jest ukazanie wpływu pochodzenia społecznego, doświadczeń życiowych oraz spotykanych na drodze naukowej mistrzów - na kształtowanie się zainteresowań przyszłego historyka wychowania. Szczególną wartość dla badań nad dziejami historii wychowania stanowi przeprowadzona przez autorkę analiza źródeł historycznych, obrazująca kolejne etapy awansu akademickiego Antoniego Karbowiaka: egzamin doktorski oraz kolokwium habilitacyjne, na którym prezentował pierwszą w Polsce pracę habilitacyjną z zakresu historii wychowania: Wychowanie fizyczne Komisji Edukacji Narodowej $w$ świetle historii pedagogii. Będąc pierwszym historykiem wychowania z tytułem docenta, Karbowiak mógł skutecznie dążyć do usamodzielnienia się tej gałęzi wiedzy oraz podniesienia poziomu nauczania akademickiego $\mathrm{z}$ zakresu tego przedmiotu.

Trzecia część książki ukazuje doniosłą rolę Antoniego Karbowiaka we współtworzeniu polskiej historii wychowania. Autorka zaprezentowała jego koncepcje odnoszące się do historii wychowania jako dyscypliny naukowej w sposób wyrazisty, akcentując postulaty Karbowiaka dotyczące potrzeby podniesienia jakości i zintensyfikowania prac badawczych w tej dziedzinie wiedzy, z której uzyskał habilitację. Swoje wywody autorka rzetelnie udokumentowała, czerpiąc informacje przede wszystkim z licznych tekstów napisanych przez samego Karbowiaka na przestrzeni wielu lat pracy twórczej. W drugim rozdziale tej części pracy zostało omówionych dziewięć głównych kierunków i problemów pisarstwa historyczno-oświatowego Karbowiaka: dzieje szkolnictwa polskiego, syntez dziejów wychowania i szkół w Polsce, polskie koncepcje wychowawcze, problematyka Komisji Edukacji Narodowej, dzieje Uniwersytetu Jagiellońskiego, literatura i sztuka a historia wychowania, historia czasopism pedagogicznych, szkolnictwo polskie poza granicami kraju oraz oświata polska pod zaborami. Ostatnie rozdziały stanowią dopełnienie sylwetki naukowej historyka wychowania. Znajdziemy w nich wykaz publikacji recenzowanych przez Profesora, charakterystykę niepublikowanych rękopisów jego autorstwa oraz opis prowadzonej przez niego działalności edytorskiej.

Sporządzenie dogłębnej analizy życia i twórczości Antoniego Karbowiaka wydaje się być wysiłkiem szczególnie cennym, gdyż jak dotąd brakuje monografii poświęconych tym polskim uczonym, których działalność naukowa skupiała się na historii wychowania i oświaty. Do tej pory dorobek Antoniego Karbowiaka, podobnie jak innych historyków wychowania, był omawiany głównie w ramach artykułów naukowych, czy ksiąg jubileuszowych. Publikacja Agnieszki Wałęgi uzupełnia zatem wciąź istniejące braki w zakresie biografistyki pedagogicznej poświęconej osobom zasłużonym dla historii wychowania dyscypliny akademickiej, której początek sięga działalności Hugona Kołłątaja, uważanego zresztą za jej twórcę ${ }^{1}$.

\footnotetext{
${ }^{1}$ Zob. W. Jamrożek, W czterdziestolecie Zakładu Historii Wychowania, w: Ad novum fructum. $Z$ okazji jubileuszu poznańskich historyków wychowania, Poznań 2007, s. 13; J. Hellwig, Prolegomena do historii wychowania, Poznań 1995, s. 19.
} 
Miejmy nadzieję, że książka poświęcona pierwszemu polskiemu uczonemu, który habilitował się $\mathrm{z}$ historii wychowania, stanie się dobrym początkiem dla publikacji poświęconych wybitnym badaczom dziejów edukacji w Polsce.

Mikolaj Brenk

\section{Z dziejów ruchu harcerskiego. Studia - Szkice - Materialy 1911-2006, pod red. E. Czop, Oficyna Wydawnicza „Mercator”, Rzeszów 2006}

Przedłożona do recenzji książka stanowi pokłosie sympozjum naukowego, które odbyło się w Rzeszowie w dniach 9-11 września 2006 r.. Sympozjum zorganizował Instytut Historii Uniwersytetu Rzeszowskiego w kooperacji z Podkarpacką Komendą ZHP. Impuls do jego zwołania dała zbliżająca się setna rocznica narodzin skautingu i dziewięćdziesiąta piąta rocznica powstania pierwszych drużyn skautowych w Polsce.

Tematem przewodnim prezentowanej publikacji są dzieje ruchu harcerskiego na ziemiach polskich w latach 1911-2006. Szerokie ujęcie zagadnienia i podana cezura czasowa sugerują wielopłaszczyznowość podjętych rozważań i ich interdyscyplinarność. Autorami zamieszczonych w zbiorze tekstów są zarówno pedagodzy, lekarze, jak i historycy. Fakt ten pozwala na uchwycenie badanego problemu w różnych perspektywach i tym samym ubogaca wiedzę odbiorcy. Po wtóre, jak na publikację posympozjalną jest ona dość nietypowa, bo łączy w sobie refleksję naukową i tę, którą pisze praktyka życia harcerskiego. Obok rozważań czysto naukowych są bowiem i te, które napisali działacze harcerscy, którzy na co dzień zajmują się szerzeniem tradycji harcerskiej.

Wspomniana interdyscyplinarność, szeroka cezura czasowa, jak i połączenie narracji naukowej z popularyzatorską spowodowało, że opracowanie zgłoszonych tekstów mogło stanowić dla organizatorów duże wyzwanie. Końcowy efekt ich pracy przekonuje, że z powierzonego im zadania wyszli obronną ręką, gdyż całość charakteryzuje się dużym stopniem spójności wewnętrznej.

Publikacja zyskała układ tematyczno-chronologiczny i składa się z ośmiu podstawowych części, w których skład wchodzi od jednego do siedmiu opracowań. Poza sformalizowanym podziałem znajduje się gawęda profesora Zbigniewa Mańkowskiego, która stanowi doskonały wstęp do zasadniczych rozważań. Gawęda ma charakter wspomnieniowy i przywołuje działalność profesora $w$ harcerstwie okręgu łańcuckiego w drugiej połowie lat 40. XX w. Był to czas dramatyczny w historii Polski, a ingerencja świata polityki w świat organizacji młodzieżowych - w tym harcerstwa - szczególnie agresywna. Świadczą o tym właśnie powyższe wspomnienia, w których profesor nieraz nadmienia o wysiłkach decydentów w kierunku upolitycznienia działalności drużyn harcerskich. Efektywność tych oddziaływań była jednak różna, a zjawiskiem bardzo charakterystycznym było to, że jakby na przekór inwigilacji, zastraszaniu i konkretnym aktom terroru wobec harcerzy, organizacja starała się prowadzić w miarę normalną (biorąc pod uwagę ówczesną sytuację społeczno-polityczną) działalność statutową.

Wątek oddziaływania czynników politycznych na funkcjonowanie ZHP przewija się zresztą niemalże we wszystkich zamieszczonych $w$ omawianym zbiorze publikacjach. 